\title{
THE DIFFERENT CONCEPT OF POSITIVE AND NEGATIVE POLITENESS OF BROWN AND LEVINSON TOWARD INDONESIAN LANGUAGE THROUGH SECOND PERSON PRONOUN ANALYSIS
}

\author{
Agung Tri Wahyuningsih, S.S., M.Pd. \\ Fakultas Ilmu Budaya - Universitas Jember \\ e-mail: agungtri.wahyuningsih@gmail.com
}

\begin{abstract}
This article is trying to see the great difference of positive and negative politeness concept proposed by Brown and Levinson by looking at different second person pronouns of English and Indonesian language. Politeness which ties the use of language universally exists in any language, though the concept is uniquely different. Brown and Levinson's (1987) proposition of the concept of politeness, despite fruitfully enriching our understanding, could not escape criticism of several points one of which is the relevance of cultural norm. Cultural norm relying substantially on the language use, therefore, governs the people's use of the language appropriately and properly which necessitates the interplay between dictions and meaningful context. In short, this article will review one marker of politeness, i.e. second person pronouns in English and Indonesian to reveal the great difference in running politeness strategies.
\end{abstract}

Keywords: pronouns, negative politeness, positive politeness, English, Indonesian 


\section{BACKGROUND}

Doing communication across culture needs more than that of which is called a language as the tool. Culture which covers language as one of its aspects guides people to achieve mutual understanding in running communication. However, different cultures may have different set of rules which are proven to be troublesome for speakers in building the harmony of communication. Bowe and Martin suggest that people of different cultural background should be aware of different aspects of context, including cultural expectation, social relation, and the purpose of communication in doing intercultural communication (2009: 3). Therefore, understanding other cultures is a desperate need for people to build intelligible communication with others coming from different cultures, i.e. intercultural communication.

Different marks are observable in any language that attaches the notion of politeness (Bowe and Martin, 2009: 3). Watt (2003: 1) characterizes politeness - in terms of language use - as respectful forms of address like (in English) Sir or Madam, and some formulaic utterances like please, thank you, excuse me, etc. Wardhaugh (2006: 260) mentions $\mathrm{T}(\mathrm{Tu})$ and $\mathrm{V}(\mathrm{Vu})$ forms of pro-nominal choices of naming and address terms which also indicate politeness markers. Brown and Attardo (2000: 80) explain that Japanese people have separate politeness markers depending on who is being honored. The speaker honors the addressee by "lowering" him-or-herself with linguistic markers, for example musuko becomes gusoku (a humble word for son) to mark humility. In line with the concept of humiliation, Javanese people, as Sukarno (2010: 65) explains, keep the concept of andhap-asor which means lowering oneself while exalting others. This politeness concept is reflected through the choice of honorifics in their speech style, for example the word dhahar and nedho which both mean "eat". To respect the addressee, the speaker uses the word dhahar when the action is supposedly performed by the addressee. Respectfully, when the speaker refers to him/herself, the word nedho is used.

Politeness markers which are obviously different across cultures may manifest into distinct, or else inappropriate lexical items that may, as well, invite different interpretations due to different cultural conceptualizations of the speakers who belong to different cultural groups (for cultural group belonging that may emerge as cultural cognition, see Sharifian, 2011). Eventually, this, potentially, leads to misunderstanding in the context of intercultural communication. The forms of address as one of politeness markers as seen on the paragraph above are the examples of language use which should be employed based on cultural consideration. When people straightforwardly carelessly translate the forms of address of other culture into their speech, they probably will not really get the real sense or capture the flavor of its original intent. Brown and Attardo (2000: 81) suggest that "in order for a person to be able to speak in manner that is socially acceptable, he/she must absorb the culture's rules. ... Forms of address are important part of behaving correctly within culture, and native speakers are skilled at using them." Therefore, to avoid misunderstanding, learning the use of appropriate forms of address and trying to feel their culturally native sense are compulsory.

In this article, the writer's interest is exploring the different forms of address between Indonesian and English which influence the understanding of politeness theory proposed by Brown and Levinson (1987). However, Maha (2014:59) declares that many researchers proved that the politeness theory of Brown and Levinson works well in western society but not for Asian communities. This article is focused on analyzing the second person pronoun as the form of address in both Indonesian and 
English to see the concept in posing others as the addressee. To start with, English has now one form of "YOU" which releases English speaking people from dilemma of choosing between formal and informal (Brown and Attardo, 2000: 81). On the contrary, Indonesian has kamu, kau, engkau, anda, dikau, saudara dan kalian. The choice of those forms of address is influenced by social aspects of the addressee. From this difference, Indonesian people unconsciously pose others unequally from them because of those alternative deictics. However, English speaking people who only have one, pose equally the addressees. This concept influences the way how Indonesian people fail to understand the concept, especially "negative politeness" by Brown and Levinson.

\section{MATERIAL AND METHODS}

\section{A. Brown and Levinson's Concept of Positive and Negative Politeness}

Brown and Levinson (2006: 311) denote the term 'face' in their proposition about politeness. Face is defined as "the public self-image that every member wants to claim for himself, which consisting of 2 aspects", namely;

a. Positive face $=$ the positive consistent self-image or 'personality' (crucially including the desire that self-image be appreciated and approved of) claimed by interactants.

b. Negative face $=$ the basic claim to territories, personal preserves, right to nondistraction,

i.e., to freedom of action and freedom from imposition.

The concept of face clearly shows that people may possess both positive and negative face when they are in a conversation. It depends on how someone else whom they are talking to treats them. Therefore, 'face' - someone self-image/wants - is the desire which cannot be maintained only by the speaker but also by the hearer. Further Brown and Levinson (2006: 317) elaborate in detail about those two notions of politeness as follows,

Positive politeness is orientated toward the positive face of $\mathrm{H}$ (Hearer), the positive self-image that he claims for himself. Positive politeness is approachbased; it 'anoints' the face of the addressee by indicating that in some respects, S (Speaker) wants H's wants (e.g., by treating him as a member of in-group, a friend, a person whose wants and personality traits are known and liked). The potential face threat of an act is minimized in this case by the assurance that in general S wants at least some of H's wants; for example that $\mathrm{S}$ considers $\mathrm{H}$ to be in an important respects, 'the same' as he, with in-group rights and duties and expectations of reciprocity, or by the implication that $\mathrm{S}$ likes $\mathrm{H}$ so that the FTA doesn't mean a negative evaluation in general of H's face.

Understanding positive politeness should be done by the speaker because this is needed to show respect to the addressee. It is a must that the speaker has to know to whom he/she is talking to, i.e. hearer's wants. When it happens, the speaker then is able to treat the hearer based on the social dimension that the hearer possesses. When a treatment that the speaker does is in line with the hearer's expectation, positive politeness arises. Therefore, this strategy runs under reciprocity. 
Reciprocity might be realized through treating the addressee in the following ways:

- as the member of in-group

- as friend

- as person whose wants are understood

- as person whose personality traits are known and liked

The speaker who understands the hearer's want - then speaks or chooses words that reflect those ways. Consequently, the threat can be minimized because the hearer's want can be understood by the speaker. Brown and Levinson (1987) add that ". . . with positive politeness, a speaker can minimize the face threatening aspects of an act by assuring the addressee that $\mathrm{S}$ considers himself to be 'of the same kind, that he likes him and wants his wants." Further, Brown and Levinson also provide an example of the utterance 'How about cookie, then.' This utterance indicates that the speaker assures that they $(\mathrm{S}+\mathrm{H})$ are EQUAL as participants. Another diction that Brown and Levinson show to be equal participants is 'WE', like in their example utterance 'Let's get on with dinner.' (2006: 318). Therefore, understanding the hearer's wants will guide the speaker to choose the dictions which indicate their equal dimension.

Negative politeness, on the other hand, is oriented mainly toward partially satisfying (redressing) H's negative face, his basic want to maintain claims of territory and selfdetermination. Negative politeness, thus, is essentially avoidance based, and realization of negative politeness strategies consist in assurances that the speaker recognizes and respects the addressee's negative face wants and will not (or will only minimally) interfere with the addressee's freedom of action. Hence, negative politeness is characterized by selfeffacement, formality and restraint, with attention to very restricted aspects of H's self-image, centering on his want to be unimpeded. Face-threatening acts are redressed with apologies for interfering or transgressing, with linguistic or non-linguistic deference, with hedges on the illocutionary force of the act, with impersonalizing mechanism (such as passives) that the distance $\mathrm{S}$ and $\mathrm{H}$ from the act, and with other softening mechanisms that give the addressee an 'out', a face-saving line of escape, permitting him to feel that his response is not coerced.

Unlike positive politeness, negative politeness which shows hearer's territory or personal preserves, such as freedom of action and freedom from imposition, make the hearer might feel inconvenience although he/she still has freedom to do action or to give any response. This feeling of inconvenience (which is referred to face-threat) is proved by 'centering on his want to be unimpeded' through the following ways;

- apologies for interfering or transgressing

- linguistic or non-linguistic deference

- hedges on the illocutionary force of the act

- impersonalizing mechanism (such as passive)

- other softening mechanisms that give the addressee an 'out', a face-saving line of escape, permitting him to feel that his response is not coerced.

These ways or acts imply that the hearer is not posed equally with the speaker. The speaker creates social distance to the hearer. When it is done, the speaker gives a real 'out' to the addressee or selfeffacement. Brown and Levinson give example that when 
a speaker makes a request or offer to the addressee, he/she does not really want the addressee to say 'yes' unless he/she wants, and when the addresses says 'no', it minimizes the face loss (2006: 319). So, in this case, the hearer is given freedom to do action or to answer the request or offer. As the conclusion, this act indicates that when people acknowledge one another, they should pose them equally - showing positive politeness, but when they treat them unequally, it is showing negative politeness.

\section{B. Second Person Pronoun in English and Indonesian}

Pronouns are markers of personal identity in relation to group. Pronouns of address give marks to people to project personal and social identity. These pronouns are regarded to govern behavior (Bowe and Martin, 2007: 95-96). Mühlhäusler (in Bowe and Martin, 2007: 96) emphasizes that pronouns are important in social context. They do not only work in grammatical process but they also establish the division of personal space or dimension and the relation between one person and another. Thus, they portray the 'culture-specific organization of people, space and its limit within which speakers can create speech situation.' Finally from those two elaborations, it can be concluded that pronouns which are parts of grammatical features constitute people's spaces or marks that visualize personal and social identity which then regulate the way how they put themselves among others.

In English, the second person pronoun is represented by the term "you" either for formal and informal situation. "YOU" which is classified as pure pronoun refers to both singular and plural (Jayakaran, 2003: 10). There are no difference to address others whose social status is not the same with the speaker. This idea is totally unlike the proposition of Bowe and Martin and Mühlhäusler. . "YOU" without any other constituents following this word cannot be identified to acknowledge people's spaces and identity.

Indonesian language, which is dissimilar to English, has various pronouns for second person. They are kamu, anda, engkau, kau, dikau, and mu (singular) and kalian, kamu, sekalian (plural) (Admin, 2014). Those pronouns refer to the second persons, which in English, are represented in one form "YOU". The use of those pronouns must be in the frame of Indonesian norm, as Teacher (2015) denotes that the forms of address are used to address others. In addressing others, the speaker should follow the ethics and norms which means that the speaker should know to whom he/she is speaking. It clearly states that the addressee is the one who determines the use of those pronouns. By using different pronouns, the speaker definitely and surely poses the addressee in the right dimension or space. Therefore in Indonesian, pronouns indicate others' personal and social identity.

\section{DISCUSSION}

In English nowadays, people feel that pronouns which are used cause problems due to the change of status, for example a young student who has finished his doctorate program becomes colleague in a university although his age is much younger than others. Therefore some agree and are happy to use English as English allows them to avoid terms of address which perform their status, because they only have one single "YOU". Even, an American professor feels foolish to be called "Professor X" although it is common. The professor will be happier to be called by his/her first name (Brown and Gilman, 1960: 270-271). Thus, people seem to put themselves equally to break 
the tyranny of democratic manner (Cronin in Brown and Gilman, 1960: 270) which authorizes the asymmetrical power.

Malton (2001) summarizes the use of second person pronouns by showing that some pronouns have been dropped to let some other dominant pronouns work for the sake of "solidarity dimension". There were "thee", "thou", and "you". Although the use of "thou" and "you" were full with controversies, the preference to use "you" has been dominantly shown by people since the use of both "thou" and "you" was interchangeable in informal speech.

Finally, it can be drawn that the use of "you" in English refers to the second person, either singular or plural, and, either formal or informal. "You" is used solely without looking at the addressee's identity. Therefore, in this case English speaking people set their mind that basically they are equal.

Unlike English, Indonesian language, in terms of second person pronouns, has a very different concept. "You" is represented in various forms. The use of the pronouns is very much depending on the addressee. As it has been mentioned on the previous discussion, Indonesian has 9 pronouns covering both singular and plural. Here are the uses of those pronouns which are consulted to online version of the dictionary of standardized Indonesian (http://kbbi.web.id).

Table 1. The definition of Indonesian second person pronouns and their use

\begin{tabular}{ll}
\hline Second person pronouns & \multicolumn{1}{c}{ Definition and use } \\
\hline $\begin{array}{l}\text { kamu - can be singular or } \\
\text { plural }\end{array}$ & $\begin{array}{l}\text { /ka·mu/ pron jamak yang diajak bicara; yang disapa } \\
\text { (dalam ragam akrab atau kasar); }\end{array}$ \\
\hline Anda & $\begin{array}{l}\text { /An·da/ pron sapaan untuk orang yang diajak berbicara } \\
\text { atau berkomunikasi (tidak membedakan tingkat, } \\
\text { kedudukan, dan umur) }\end{array}$ \\
\hline Engkau & $\begin{array}{l}\text { /eng·kau/ pron yang diajak bicara, yang disapa } \\
\text { (dipakai untuk orang yang sama atau lebih rendah } \\
\text { kedudukannya), digunakan juga untuk berdoa kepada } \\
\text { Tuhan (Engkau); }\end{array}$ \\
\hline $\begin{array}{l}\text { kau - which is similar to } \\
\text { "engkau" }\end{array}$ & $\begin{array}{l}\text { pron engkau (umumnya digunakan sebagai bentuk } \\
\text { terikat di depan kata lain) }\end{array}$ \\
\hline dikau - which refers to the & /di·kau/ pron engkau \\
same pronoun "engkau" & \\
\hline -mu & $\begin{array}{l}\text { klitik kamu sebagai penunjuk pemilik: bukumu; } \\
\text { sepedamu }\end{array}$ \\
\hline Kalian & $\begin{array}{l}\text { /ka·li·an/ pron yang diajak bicara yang jumlahnya lebih } \\
\text { dari satu orang (dalam ragam akrab) }\end{array}$ \\
\hline Sekalian & /se·ka·li·an / 1 num semua; 2 a bersama-sama; serentak \\
\hline &
\end{tabular}

The table above indeed shows that Indonesian second person pronouns are various. "kamu" which can be singular or plural is used when the speaker and the addressee are known to each other and are showing solidarity otherwise people may say this pronoun as rude/impolite. This pronoun is impolitely used when the speaker is younger from the addressee, such as children to parents, or people whom we should 
give respect to such as teachers. Politely, this pronoun "kamu" is used among those who are the same age, or younger than the speaker. The use of "kamu" is similar to "engkau" which can be replaced with "kau" and "dikau". However, the use of "Anda" which is used without considering the addressee's social status, seems controversially debated. Kusno (Kusno, 2015) argues that the use of "Anda" could not stand equally to "you" in English. "Anda" as an address term sounds awkward when it is used to address those who are close, older, and or even younger than the speaker. When "Anda" is employed in a conversation whose speaker is very close to the addressee, it causes inconvenience to the addressee. Compared to Brown and Levinson's (1987) concept of politeness, the use of "Anda" above can be classified into "negative politeness" in which the speaker poses the addressee to some distance. In Indonesian language, the term politeness is next to impoliteness. Therefore, negative politeness, in Indonesian, may be categorized as impoliteness or to lessen its sense, it is commonly said as "awkward". The other use of "Anda" which seems impolitely applied is when it is uttered to the addressee who is older than the speaker. It is regarded as a very rude act. The speaker will be assumed as ill-mannered person. To overcome this situation, the speaker could replace "Anda" with the honorifics, such as Bapak or Ibu (depending on their sex). These nouns of address convey more respect. The last unfavorable use of "Anda" is found when it is addressed to younger hearer. It is definitely grotesque. Thus, it is a must to see the addressee's social status and age to get the rightfully respectful addressing term.

To address more than one person, Indonesian has "kalian" and "sekalian". "Kalian" is used to the addressees who are close to the speaker. It is also frequently used by the speaker who is older than the addressee, for example teacher to students. When they are in distance, the speaker usually doubles "Anda" (become "AndaAnda"). It can be done by lecturer to university students. However, when the speaker is younger than the addressees, for the sake of politeness, the speaker tends to use honorifics after doubling them, such as Bapak-Bapak and Ibu-Ibu. The use of this term is usually followed by "sekalian". This "sekalian" can be attached to any noun of address, such as anak-anak "sekalian", which means addressing all children. So, "sekalian" is identical with "all" in English.

Finally from both English and Indonesian second person pronouns, it can be inferred that the way how both languages pose others is very different. English poses others EQUALLY, while Indonesian poses others UNEQUALLY. It might be done unconsciously, but it is represented in the way how they choose word/words to represent others. English has merely one "YOU", but Indonesian has "kamu, engkau, kau, dikau, anda, -mu, kalian, and sekalian". In terms of politeness, Brown and Levinson's concept of "positive" and "negative" politeness might be misleading for Indonesian, because they do not have the term "negative". This negative politeness is possible to be replaced by "awkwardness", or sometimes it is considered impolite.

In seeing the following example given by Brown and Levinson, Indonesian sees them as contradictory expression (http://www.mona.uwi.edu/dllp/linguistics/ politeness.htm). The negative politeness seems more polite.

Positive Politeness: Is it O.K. if I use one of those pens?

In this situation we recognize that your teacher has a desire to be respected. It also confirms that the relationship is friendly and expresses group reciprocity.

Negative Politeness: I am sorry to bother you but, I just want to ask you if I could use one of those pens? 
Similar to the Positive Politeness in that you recognize that they want to be respected however, you also assume that you are in some way imposing on them. Some other examples would be to say, "I don't want to bother you but." or "I was wondering if..."

The context of the examples above is a student is asking a pen to his/her teacher. Categorized as positive politeness, the student as the speaker poses the teacher with in-group, or equal member of the group. This phenomenon is in line with the previous elaboration in which a professor does not want to be called "Professor". This idea strengthens the concept of EQUALITY among those English speaking people. The equality among people is realized in the concept of individual, which according to Leech (2014: 295-296) "One of the characteristics of individualist societies is that everyone is assumed to have a right to self-determination and privacy".

Unlike positive, negative politeness utterance above is considered as a way to impose the teacher to lend him/her a pen. Through the expression "I am sorry to bother you...." which means that the student is disturbing the teacher to give him/her time. This expression is usually spoken to those whose relation is not close. In this studentteacher dyad, they are assumed to be close because they have known each other. Thus, when the student is expressing that utterance, he/she tries to create distance with his/her teacher.

Compared to Indonesian concept of politeness, the different concept may be found. A teacher is someone who should be respected. Therefore, there is a distance between teacher and student. The student should not assume his/her teacher is equal with him/her. He/she should put the teacher above him/her which means that the teacher should be honored. For the sake of politeness, positive politeness utterance is possibly said as polite utterance in Indonesian "Is it O.K. if I use one of those pens?" - Apa boleh saya pinjam satu dari pulpen-pulpen itu? However, negative politeness utterance, when translated into Indonesian, seems more polite than positive one "I am sorry to bother you but, I just want to ask you if I could use one of those pens?" - Maaf mengganggu, saya mau tanya (pada Bapak/Ibu), apakah saya bisa pinjam satu dari pulpen-pulpen itu? That expression gets more polite sense rather than the previous one. However, the problem that may arise is that the use of pronoun "YOU". Because the second person is a teacher to whom the student should give big deference, the addressing terms "kamu, engkau, kau, dikau" are not the right pronouns to choose. It will be very rude when a teacher is addressed by the student with those pronouns.

Finally, the concept of positive and negative politeness proposed by Brown and Levinson (1987) could not be applied to Indonesian language. Pronouns which are indicators one of politeness markers are used to see the difference. English with the only "YOU" is seeing people as equal, therefore without any consideration, "YOU" is applicable to any person as the addressee. On the contrary, Indonesian language has some sorts of pronouns which do not resemble the English "YOU" thus it has one certain consequence that the speaker should see others unequally. The speaker should think carefully about the addressee's identity as the clue to lead the speaker to choose the right pronouns. Additionally, Indonesian language does not have the term "negative" politeness. Indonesian people classify that manner into "polite" and "impolite". With regard to the word "negative" which is indicated as something "not good", Indonesian students may think that negative means impolite. Related to pronouns used, there is a great difference in using the expression. Negative politeness utterance is possibly assumed as polite, even more polite. 


\section{CONCLUSION}

The main point to sum up in this discussion is that it is the pronouns which then regulate people to use the concept of politeness. Besides, pronouns imply the way how people see others. Related to politeness, pronouns give great influence to create the sense. "YOU" in English could not stand similarly to "kamu, kau, engkau, anda, and kalian" in Indonesian. It indicates that English speaking people think others indifferent or equal, while Indonesian speaking people think that others are different or unequal. Therefore, to replace "YOU" with Indonesian pronouns, some consideration must be employed. In relation to positive and negative politeness, Indonesian language which does not possess the two terms, may assume that negative is impolite. In fact negative politeness utterance seems more polite than positive one. Therefore, this great different concept should be understood more to avoid any misleading assumption in seeing others.

\section{REFERENCES}

Admin. 2014. "Kata Ganti (Promina) Bahasa Indonesia" (http://www.ebahasaindonesia.com/2014/11/kata-ganti-promina-bahasa indonesia.html), accessed on May 31, 2016, at 6:19 pm.

Bowe, Heather and Martin, Kylie. 2007. Communication across Cultures. Mutual Understanding in a Global World. Cambridge: Cambridge University Press.

Brown, R and Gilman, A. "The Pronouns of Power and Solidarity" in T.A. Sebeok (Ed), Style in Language, MIT Press, 1960, pp 253-76

Brown, Steven and Attardo, Salvatore. 2000. Understanding Language Structure, Interaction, and Variation. An Introduction to Applied Linguistics and Sociolinguistics for NonSpecialists. Michigan: The University of Michigan Press.

Brown, Penelope and Levinson, Stephen C. 1987. "Politeness: Some Universals in Language Usage" in Adam and Nikolas Coupland (Eds), The Discourse Reader, New York: Routledge, 2006. pp 311-23

Jayakaran, I. 2003. Everyone's Guide to English Grammar (A New Approach). Chennai: Apple Publishing International (P) Ltd.

Kusno, Gustaaf. 2015.” Menyapa dengan Kata 'Anda', Sopankah?” (http://www.kompasiana.com/gustaafkusno/menyapa-dengan-kata andasopankah_55173cb781331189669de3fc), accessed on June 2, 2016, at 7:11 pm

Leech, Geoffrey N. 2014. The Pragmatics of Politeness. New York: Oxford University Press

Maha, Lounis. 2014. "Cross-Cultural Perspectives on Linguistic Politeness". CrossCultural Communication Journal. Vol. 10, No. 1, 2014, pp. 56-60

Malton, Sara. 2001. "Development of the Second-Person Pronoun" (http://homes.chass.utoronto.ca/ cpercy/courses/6361Malton.htm), accessed on June 1, 2016, at 11:23 pm 
Sukarno. 2010. "The Reflection of the Javanese Cultural Concepts in the Politeness of Javanese". Journal KATA. Vol.12 no.1 page: 41-58

Sharifian, Farzad. 2011. Cultural Conceptualisations and Language: Theoretical Frameworks and Applications. Amsterdam/Philadelphia: John Benjamins Publishing Company.

Teacher, Master. 2015. "Pengertian dan Contoh Kata Ganti Orang" (http://www.berpendidikan.com/2015/05/pengertian-dan-contoh-kata-gantiorang.html), accessed on May 31, 2016, at 6:30 pm.

The University of the West Indies, 2016. "Politeness"

(http://www.mona.uwi.edu/dllp/linguistics/politeness.htm), accessed on June 4, 2016 , at 7:39 pm

Wardhaugh, Ronald. 2006. An Introduction to Sociolinguistics. MA: Blackwell Publishing.

Watts, Richard J. 2003. Politeness. Cambridge: Cambridge University Press 